Schandl, Veronika. "Glajar, Valentina, Alison Lewis and Corina L. Petrescu (eds.). 2016. Secret Police Files from the Eastern Bloc - Between Surveillance and Life Writing. Rochester, NY: Camden House, Boydell and Brewer. 237 pp.” Hungarian Cultural Studies. e-Journal of the American Hungarian Educators Association, Volume 10 (2017) DOI: 10.5195/ahea.2017.305

\title{
Glajar, Valentina, Alison Lewis and Corina L. Petrescu (eds.). 2016. Secret Police Files from the Eastern Bloc-Between Surveillance and Life Writing. Rochester, NY: Camden House, Boydell and Brewer. 237 pp.
}

\section{Reviewed by Veronika Schandl*, Pázmány Péter Catholic University, Budapest}

After the fall of the Socialist regimes in East-Central Europe, one important phase of the aftermath of Socialism was the opening of the state archives containing the secret-police files of that era. Although some of the documents were destroyed during the frantic days of the regime change, historians and citizens alike were still left with an immense load - both practically and emotionally. The amount of surveillance the archives reveal is staggering. For instance, Lavinia Stan has calculated that the East-German or GDR Stasi archives alone are estimated to cover around 180 kilometers, if the papers in it were to be laid one after another. Therefore, these archives will probably provide work for researchers in the upcoming decades. And as for the emotional, psychological load, we can imagine how the lives of the people affected by the information in these files, victims and perpetrators alike, drastically changed in many ways once the information in the files became public.

Traditional researchers would see the files as sources, as historical thumbprints of a bygone era, and thus they might overlook the personal aspects of these documents. Secret Police Files from the Eastern Bloc - Between Surveillance and Life Writing, edited by Valentina Glajar, Alison Lewis and Corina L. Petrescu, decidedly goes the other way. Focusing on the informants, rather than on the victims of surveillance, the chapters or in fact independent articles included in it aim at reading the personal files of recruited informants, not of the persons they reported on. This way the records are analyzed not as sources, but as life writings, or as what the editors phrase in their Introduction as "hostile, un-authorized biographies" (9). Accordingly, the eight articles of the book examine fragmented life stories as deciphered from the GDR Stasi, Romanian Securitate, and Hungarian Államvédelmi Hatóság or ÁVH documents.

Taking into account the fact that the files were written in a jargon specific to their time and purpose, and not forgetting that they must always be treated as unreliable narratives where truth mingles with manipulative fiction, the volume turns to poststructuralist and discourse criticism, as well as to performance theory, to contextualize these texts. The Introduction promises empathy and compassion besides an ethical and duly critical reading of the files to enable them to come across as biographical narratives of persons and institutions; but at its best it

*schandl.veronika@btk.ppke.hu

$($ (c) $)$ EY

ULIS D-Serk
New articles in this journal are licensed under a Creative Commons Attribution 4.0 International License.

This journal is published by the University Library System of the University of Pittsburgh as part of its D-Scribe Digital Publishing Program and is cosponsored by the University of Pittsburgh Press 
Schandl, Veronika. "Glajar, Valentina, Alison Lewis and Corina L. Petrescu (eds.). 2016. Secret Police Files from the Eastern Bloc - Between Surveillance and Life Writing. Rochester, NY: Camden House, Boydell and Brewer. 237 pp." Hungarian Cultural Studies. e-Journal of the American Hungarian Educators Association, Volume 10 (2017) DOI: 10.5195/ahea.2017.305

achieves something more, namely, establishing a discourse of the secret-police files as life writings. The common thread at the backbone of all the articles is their engagement with the fragmented nature of the archival documents they study. The task of the researcher is to discover how the disjointed pieces of the accounts foreground questions of identity, how they are used in their afterlife to reclaim one's biography, and how they function as narratives, as counternarratives, or as performances. Never denying the importance of interpretation, the various articles thus offer insightful readings of the once secret lives of the Soviet bloc informants.

The volume is organized into three main parts: the first is entitled "File Stories" and deals with the personal fates of informants, while the second part of the book concerns itself with narrative fiction and personal memory, and the third part turns to performative and collective memory. Opening the first part, Alison Lewis's article first gives a useful introduction to the general nature of Stasi files, and then it shows how people's public personae clashed with or got integrated into their lives as secret informants. This article's main interest, using Pierre Bourdieu's idea of "habitus" as meaning "the unifying, generative principle of all practices" (30) guiding one's actions, lies in its drawing of the portraits of three informants and the driving forces behind their collaboration with the Stasi. We get, for example, a precise description of Paul Wiens, a loyal Stasi agent, who enjoyed the travels and the international recognition his loyalty brought him; or of his daughter Maja, who became an enemy of the state after having served as its informant; or of Sascha Anderson, a subversive iconoclast, who believed that his reports would positively influence the regime's attitude toward arts and artists.

While Lewis stresses what she calls the "pedestrian" nature of the files she examines, in the second article we are introduced to a narrative of love, betrayal and loss, fit for a spy novel, as even its author Valentina Glajar admits. The Securitate files discussing the fate of the agent codenamed "Fink Susanne" reveal the story of a young Romanian woman who fell in love with and then married a West-German man. With the promise that she would be able to visit her husband in Germany, she was coerced into reporting on Romanian Saxon intellectuals she knew. In the end, she was not able to meet with her husband and had to divorce him, which eventually made her turn against the Securitate. Exciting as her story is in itself, it also sheds light on the recruitment and interrogation techniques of the Securitate, which the article seems eager to disclose and depict.

In her thorough analysis of Eginald Schlattner's role as a witness in the German Writers' Trial in Romania, Corina L. Petrescu, one of the editors of the volume, traces how Schlattner, a noted writer by then, tried to defend himself in his novel after his files became public. Following this line of thought, the second part of the book deals primarily with writers reinterpreting in their fiction their own past as secret-police informants. Annie Ring explores, through the examples of Monika Maron and Christa Wolf, how the revelation of one's past as informant caused a breakdown in one's personal life and how these two authors fictionalized this collapse in their novels. Carol Anne Costabile-Heming looks at Jana Döring's semi-fictional biographical novel Stasiratte, which questions the role of its protagonist as a perpetrator, and wishes to show why the decision of Döring's protagonist to become an informant made perfect sense in the narrow world of the GDR.

In the third part of the volume, devoted to performative and collective memory, Ulrike Garde analyzes two German documentary-theater performances, both primarily using the voices 
Schandl, Veronika. "Glajar, Valentina, Alison Lewis and Corina L. Petrescu (eds.). 2016. Secret Police Files from the Eastern Bloc - Between Surveillance and Life Writing. Rochester, NY: Camden House, Boydell and Brewer. 237 pp." Hungarian Cultural Studies. e-Journal of the American Hungarian Educators Association, Volume 10 (2017) DOI: 10.5195/ahea.2017.305

and real-life stories of people appearing in Stasi documents, and then setting them against their respective Stasi files. In doing so she explores issues of authenticity and affect; namely, how these productions create and preserve a sense of authenticity by mingling fact and fiction, personal and official narratives, and "how they affect the protagonists and the audience's roles as potential witnesses of past traumatic events" (180). Similarly, Yuliya Komska addresses issues of audience influence when discussing the Romanian documentary Cold Waves (2007) about the role of Radio Free Europe (RFE) during the dictatorship of Nicolae Ceaușescu. Komska indicates that director Alexandru Solomon's use of montage cannot but echo the techniques of Russian agitprop movies aimed at shaping public opinion through oppressive and unreliable picture, sound, and effect manipulations. Komska in fact argues that when used in a documentary about clandestine material that was suppressed during the Soviet Era, the format becomes deconstructed by the content.

As evident from the articles surveyed so far, the volume's focus is primarily on German or ethnic German materials. Therefore, Aniko Szucs's article, in which she discusses Kriszta Kovács and Géza Bereményi's play Apacsok (2009) ['Apaches on the Danube' (English trans. by Lucy Frankel)], is the one article in the book that deals with Hungarian secret-police affairs. Based on real events, but not with the purpose of exposing any real people, the play is set in the home of a present-day family and it mixes up three timelines, thus eventually revealing a family secret. A group of young people in 1960s Hungary decides to live like Native Americans in the Bakony hills in Transdanubian, Northern Hungary. Their tribal brotherhood is shaken - in reality and in the play as well - when one of them starts sending reports on the group to the ÁVH. The play examines the possible consequences of lying and ignoring reality by tracing the changes within this family when the truth is finally revealed. Szucs's article is interested in how the play's reliance on existing ÁVH files, or what she calls its "document affect," makes the audience experience a "history affect" regarding the 1960s in Hungary.

Through its reconstruction, rewriting and deconstruction of past events in personal narratives found in Soviet-ruled secret-police agencies, Secret Police Files from the Eastern Bloc takes the reader to a journey into the everyday life of the darkest days of East-Central Europe. Although addressing mainly scholarly audiences, this book also discusses issues of interest to wider audiences. 